\title{
Combining Nanoconfinement in Ag Core/Porous Cu Shell Nanoparticles with Gas Diffusion Electrodes for Improved Electrocatalytic Carbon Dioxide Reduction
}

\author{
João R. C. Junqueira, ${ }_{,}^{[a]}$ Peter B. O'Mara, ${ }^{[b]}$ Patrick Wilde, ${ }^{[a]}$ Stefan Dieckhöfer, ${ }^{[a]}$ \\ Tania M. Benedetti, ${ }^{[b]}$ Corina Andronescu, ${ }^{[c]}$ Richard D. Tilley, ${ }^{[b, d]}$ J. Justin Gooding, ${ }^{[b]}$ and \\ Wolfgang Schuhmann ${ }^{*[a]}$
}

Bimetallic silver-copper electrocatalysts are promising materials for electrochemical $\mathrm{CO}_{2}$ reduction reaction $\left(\mathrm{CO}_{2} \mathrm{RR}\right)$ to fuels and multi-carbon molecules. Here, we combine $\mathrm{Ag}$ core/porous $\mathrm{Cu}$ shell particles, which entrap reaction intermediates and thus facilitate the formation of $\mathrm{C}_{2+}$ products at low overpotentials, with gas diffusion electrodes (GDE). Mass transport plays a crucial role in the product selectivity in $\mathrm{CO}_{2} \mathrm{RR}$. Conventional $\mathrm{H}$ cell configurations suffer from limited $\mathrm{CO}_{2}$ diffusion to the reaction zone, thus decreasing the rate of the $\mathrm{CO}_{2} \mathrm{RR}$. In contrast, in the case of GDE-based cells, the $\mathrm{CO}_{2} \mathrm{RR}$ takes place under enhanced mass transport conditions. Hence, investigation of the $\mathrm{Ag}$ core/porous $\mathrm{Cu}$ shell particles at the same potentials under different mass transport regimes reveals: (i) a variation of product distribution including $C_{3}$ products, and (ii) a significant change in the local $\mathrm{OH}^{-}$activity under operation.

\section{Introduction}

Alongside the increase in the concentration of atmospheric $\mathrm{CO}_{2}$, the interest in suitable materials for the $\mathrm{CO}_{2}$ reduction reaction $\left(\mathrm{CO}_{2} \mathrm{RR}\right)$ to valuable fuels and chemicals is growing significantly. ${ }^{[1]}$ The $\mathrm{CO}_{2} \mathrm{RR}$ is a complex reaction that occurs via multi proton-coupled electron transfer steps and many different intermediates under the formation of various products. ${ }^{[2,3,4]}$ The selectivity of single metals for the $\mathrm{CO}_{2} \mathrm{RR}$ have been previously investigated. Ag, for instance, shows an almost exclusive

[a] J. R. C. Junqueira, Dr. P. Wilde, S. Dieckhöfer, Prof. Dr. W. Schuhmann Analytical Chemistry - Center for Electrochemical Sciences (CES)

Faculty of Chemistry and Biochemistry,

Ruhr-Universität Bochum

Universitätsstraße 150,

D-44780 Bochum, Germany

E-mail: Wolfgang.Schuhmann@ruhr-uni-bochum.de

[b] P. B. O'Mara, Dr. T. M. Benedetti, Prof. Dr. R. D. Tilley, Prof. Dr. J. J. Gooding School of Chemistry and Australian Centre for NanoMedicine

University of New South Wales

Sydney 2052, Australia

[c] Prof. Dr. C. Andronescu

Chemical Technology III

Faculty of Chemistry and CENIDE,

Center for Nanointegration

University Duisburg Essen

Carl-Benz-Straße 199, D-47057 Duisburg, Germany

[d] Prof. Dr. R. D. Tilley

Electron Microscope Unit

Mark Wainwright Analytical Centre

University of New South Wales

Sydney 2052, Australia

Supporting information for this article is available on the WWW under https://doi.org/10.1002/celc.202100906

Of $\odot 2021$ The Authors. ChemElectroChem published by Wiley-VCH GmbH. This is an open access article under the terms of the Creative Commons Attribution Non-Commercial NoDerivs License, which permits use and distribution in any medium, provided the original work is properly cited, the use is non-commercial and no modifications or adaptations are made. formation of $\mathrm{CO}$, whereas $\mathrm{Cu}$ is the only single metal reported to produce multi-carbon molecules; however, with insufficient selectivity and unsatisfactory long-term stability. ${ }^{[4-6]}$ In bimetallic $\mathrm{AgCu}$ catalysts, the combination of two different active sites improves the product distribution through enhanced selectivity towards $\mathrm{C}_{2+}$ products at comparatively low overpotentials. ${ }^{[4,7]}$ The improved performance originates from a reaction cascade, in which at the first step $\mathrm{Ag}$ centres can efficiently reduce $\mathrm{CO}_{2}$ to $\mathrm{CO}$ at a low overpotential, ${ }^{[8]}$ followed by further reduction of $\mathrm{CO}$ intermediate on $\mathrm{Cu}$ sites to $\mathrm{C}_{2}$, molecules at a lower applied potential and with higher selectivity if compared to Cu-only catalysts. ${ }^{[6,9]}$ The desorption of a $\mathrm{CO}$ molecule from one active site and the transport and re-adsorption at another one is known as CO spill-over mechanism. ${ }^{[10,11]}$ In this context, bimetallic AgCu nanoparticles are an interesting material, where the structure of the particles strongly influences the $\mathrm{CO}_{2} \mathrm{RR}$ product distribution. ${ }^{[4,12,13,14-16]}$ For example, $\mathrm{AgCu}$ nanodimer particles showed a faradaic efficiency (FE) for ethylene of up to $\sim 38 \%$. $^{[14]}$

Most studies with $\mathrm{AgCu}$ bimetallic catalysts use conventional H-cell set-ups, in which the catalyst-modified electrode is completely immersed in a $\mathrm{CO}_{2}$-saturated electrolyte. ${ }^{[5,9,10,12,14]}$ Assessing the $\mathrm{CO}_{2} \mathrm{RR}$ performance of catalysts with this cell design has, however, inherent limitations, which are primarily related to the long $\mathrm{CO}_{2}$ diffusion pathways. Hence slow mass transport from the bulk of the electrolyte to active centres of the catalyst. Therefore, $\mathrm{CO}_{2}$ is quickly depleted in the vicinity of the active catalytic centres, limiting its conversion, and preventing the assessment of the full capability of the catalyst material (Scheme 1d). Moreover, in this scenario, the rate of the parasitic hydrogen evolution reaction (HER) is promoted. In contrast, gas diffusion electrodes (GDEs) are known to enable a higher flux of the gaseous reactant to the catalyst through shorter diffusional pathlengths leading to higher $\mathrm{CO}_{2}$ concentration in the reaction 

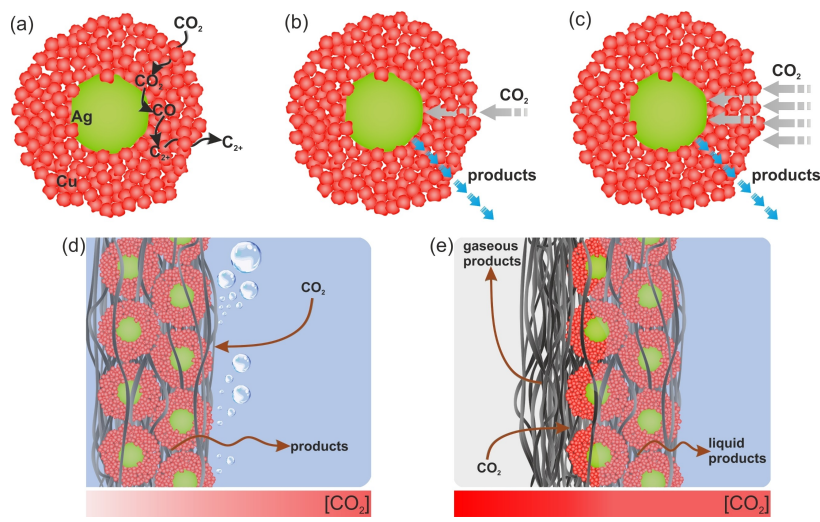

Scheme 1. (a) Representation of the cascade reaction in the Ag core/porous $\mathrm{Cu}$ shell particle. (b) The reaction is limited by $\mathrm{CO}_{2}$ depletion from the bulk and only a small amount of $\mathrm{CO}_{2}$ reaches the catalyst particle. (c) The reaction is limited by the $\mathrm{CO}_{2}$ mass transport inside the porous $\mathrm{Cu}$ shell. (d) Comparison of the $\mathrm{CO}_{2} \mathrm{RR}$ in an $\mathrm{H}$-cell with the catalyst layer entirely immersed within the electrolyte and (e) the GDE-based electrochemical cell. Local $\mathrm{CO}_{2}$ concentration is indicated by colour gradient with red colour indicating high and white indicating low concentrations.

zone (Scheme 1e) and establishing higher currents. ${ }^{[5,17,18]} \mathrm{Cu}-\mathrm{Ag}$ tandem catalysts measured with a GDE show a production rate of around $-160 \mathrm{~mA} / \mathrm{cm}^{2}$ for $\mathrm{C}_{2+}$ products. ${ }^{[19]}$ The CuAg is not the only possible combination for cascade reactions, other tandem catalysts measured in GDE cells were reported with a high production rate for $\mathrm{C}_{2+}$ products reaching up to $-367 \mathrm{~mA} / \mathrm{cm}^{2}$ with $\mathrm{Cu} / \mathrm{ZnO} / \mathrm{C}^{[20]}$ and $-415 \mathrm{~mA} / \mathrm{cm}^{2}$ using $\mathrm{Cu} /$ $\mathrm{Ni}-\mathrm{N}-\mathrm{C} .^{[21]}$

In contrast to bimetallic and tandem catalyst structures, where various active centres are directly exposed to the electrolyte, the $\mathrm{Ag}$ core/porous $\mathrm{Cu}$ shell catalyst used in this work exhibits a unique structure with a Ag core, which is surrounded by a porous $\mathrm{Cu}$ shell, such that the $\mathrm{CO}$ produced at the $\mathrm{Ag}$ core can react at the $\mathrm{Cu}$ shell without diffusion to the bulk (Scheme 1a). ${ }^{[22]}$ Previously, we demonstrated that the porous channel system of these nanoparticles creates a nanoconfinement leading to a locally higher $\mathrm{CO}$ concentration within the $\mathrm{Cu}$ shell that ultimately results in the formation of more complex products such as $n$-propanol at a comparatively low overpotential. ${ }^{[15]}$ The $\mathrm{CO}_{2} \mathrm{RR}$ performance of these particles is sensitive to the applied potential. At more cathodic potentials the particles experience structural changes, in which the shell breaks apart with a concomitant loss of nanoconfinement. ${ }^{[16]}$ Therefore, it is crucial to assess the selectivity of these particles under strict potential control.

The $\mathrm{CO}_{2}$ to $\mathrm{CO}$ step is essential for the formation of $\mathrm{C}_{2+}$ products. Therefore, the $\mathrm{Ag}$ core/porous $\mathrm{Cu}$ shell particles activity can be limited by either (i) low $\mathrm{CO}_{2}$ concentration at the reaction zone, caused by the $\mathrm{H}$-cell constraints (Scheme $1 \mathrm{~b}$ ), or (ii) low $\mathrm{CO}_{2}$ availability at the Ag core, caused by a restricted $\mathrm{CO}_{2}$ transport within the $\mathrm{Cu}$ shell (Scheme 1c). We hence combined the $\mathrm{Ag}$ core/porous $\mathrm{Cu}$ shell particles with GDEs to eliminate the fundamental limitations of the H-cell configuration, allowing the direct comparison of the particles' selectivity under two $\mathrm{CO}_{2}$ flux regimes. The measurements with the GDE cell allow for an evaluation of the catalyst's performance devoid of diffusional restraints and at higher currents. The presented results show an improvement in the $\mathrm{CO}_{2} \mathrm{RR}$ activity and selectivity of the $\mathrm{Ag}$ core/porous $\mathrm{Cu}$ shell particles using a GDE as compared to a $\mathrm{CO}_{2}$-saturated $\mathrm{H}$-cell. Furthermore, only measurements in the GDE cell showed the formation of $\mathrm{C}_{3}$ products, further emphasising the importance of the shorter $\mathrm{CO}_{2}$ diffusion pathways. Measurements of the $\mathrm{OH}^{-}$activity in close proximity of the operating electrodes reveal that there is a significant local variation of the $\mathrm{OH}^{-}$activity for both $\mathrm{H}$-cell and GDE cell. Nonetheless, the extent of these changes is more pronounced when the GDE cell is used.

\section{Results and Discussion}

Ag core/porous Cu shell particles were synthesised as described previously. ${ }^{[15,16]}$ The particles exhibit a Ag core with $\sim 46 \mathrm{~nm}$ diameter with a porous $\mathrm{Cu}$ shell with a thickness of $\sim 25 \mathrm{~nm}$ (Figure 1 and Figure S1). The STEM images confirm the porosity of the $\mathrm{Cu}$ shells, which is a prerequisite for the transport of $\mathrm{CO}_{2}$ to the silver core. To prevent inconsistencies related to subtle variations in particle size or catalyst structure, the same nanoparticle synthesis batch was used in all experiments. Electrodes were prepared by drop-casting a suspension of catalyst powder and PTFE particles in methanol onto carbon paper (Figure S2). New electrodes were used for each experiment performed at the different applied potentials or configurations of the electrochemical cell (Figure S3), and each electrode was measured only once to prevent influences from possible catalyst degradation.

The experiments with the GDE reached significantly higher currents than those performed in the $\mathrm{H}$-cell (Figure 2, Figure S4 and Table S1). Due to the inherent existence of an uncompensated resistance $\left(R_{\mathrm{u}}\right)$ between the working and reference electrode, the actual potential at the working electrode differs from the nominal applied potential proportionally to the magnitude of the measured current. Therefore, all measurements were performed with an automatic $i R_{\mathrm{u}}$ compensation protocol (for further details, see $\mathrm{SI}$ and Figure S5). Three potentials of $-0.50,-0.65$ and $-0.80 \mathrm{~V}$ vs. $\mathrm{RHE}_{\text {iRcor. (all the }}$ potential values in this work are given in $\mathrm{V} v s$. $\mathrm{RHE}_{i R c o r}$, see supporting information) were selected for the measurement series to give catalytic currents of $-0.7,-7.9$ and $-17.3 \mathrm{~mA}$ for the H-cell and $-3.0,-18.6$ and $-106 \mathrm{~mA}$ for the GDE cell

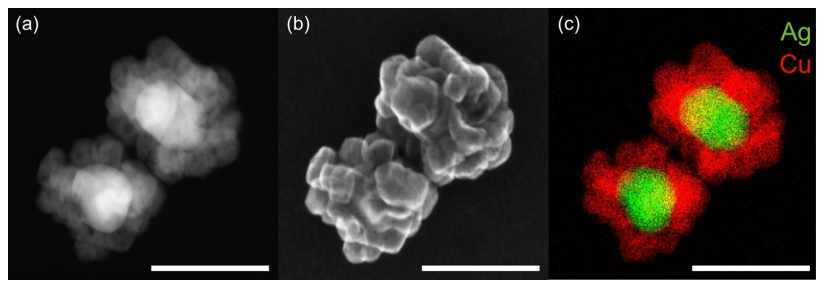

Figure 1. (a) STEM-DF, (b) SEM micrographs and (c) EDS colour map for Ag and $\mathrm{Cu}$ of the synthesised $\mathrm{Ag}$ core/porous $\mathrm{Cu}$ shell nanoparticles, scale bar corresponds to $100 \mathrm{~nm}$. 


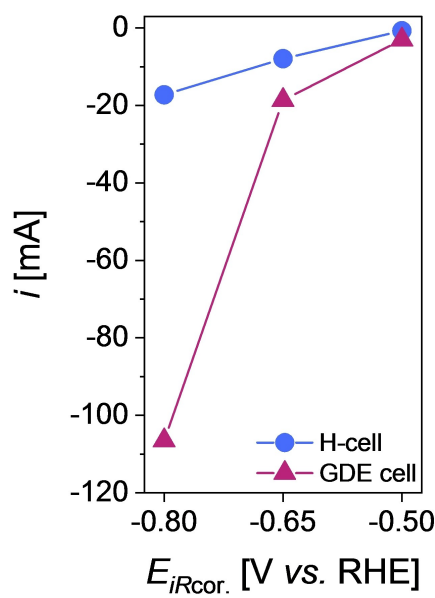

Figure 2. Average current $i$ at the end of the 1-hour long chronoamperometry vs. $E_{i k c r}$ at different applied potentials with the $\mathrm{H}$-cell and GDE cell. Catalyst loading per electrode $\sim 1.6 \mathrm{mg}, \mathrm{n}=2$.

measurements. The measured currents were 4.2, 2.3 and 6.2 times higher at the three selected potentials when performed with the GDE cell. Such high current differences underscore the necessity of the automatic $i R_{\mathrm{u}}$ compensation since they would significantly influence the actual potential at the working electrode. Moreover, such differences in the measured currents between the two cell designs suggest that for the GDE cell there could be a significant variation of the $\mathrm{pH}$ value close to the reaction zone. These changes in the $\mathrm{pH}$ value would be a direct consequence of the consumption of $\mathrm{H}_{2} \mathrm{O}$ and the release of $\mathrm{OH}^{-}$during $\mathrm{CO}_{2} \mathrm{RR}$, as demonstrated in the half cell reactions for alkaline electrolytes (see supporting information). ${ }^{[2]}$ Previously, the increase in the local $\mathrm{pH}$ value was shown to increase the production of $\mathrm{C}_{2}$ products and suppress HER. ${ }^{[23,24]}$

To ensure comparable measurements, the $\mathrm{CO}_{2} \mathrm{RR}$ experiments were performed in $1 \mathrm{M} \mathrm{KHCO}_{3}$ as the electrolyte in both types of electrochemical cells (Figure S3). Gaseous products were separated and analysed using online gas chromatography, and liquid products were quantified with ${ }^{1} \mathrm{H}-\mathrm{NMR}$ from interval aliquots (for experimental details, see supporting information). Apart from $\mathrm{H}_{2}$, six major $\mathrm{CO}_{2} \mathrm{RR}$ products, namely $\mathrm{CO}$, ethylene $\left(\mathrm{C}_{2} \mathrm{H}_{4}\right)$, formate $\left(\mathrm{HCO}_{2} \mathrm{H}\right)$, acetate $\left(\mathrm{CH}_{3} \mathrm{CO}_{2} \mathrm{H}\right)$, ethanol $\left(\mathrm{C}_{2} \mathrm{H}_{5} \mathrm{OH}\right)$, and $n$-propanol $\left(\mathrm{C}_{3} \mathrm{H}_{7} \mathrm{OH}\right)$ were quantified. Methane $\left(\mathrm{CH}_{4}\right)$ and ethane $\left(\mathrm{C}_{2} \mathrm{H}_{6}\right)$ were also identified, but with a faradaic efficiency of below $1 \%$, and hence they were not considered further (Figure S6). The activity and selectivity of the $\mathrm{CO}_{2} \mathrm{RR}$ in the GDE cell differed significantly from the results obtained in the $\mathrm{H}$-cell. The effect of the cell design goes beyond merely increasing the maximum current. Rather, the range of products, and their distribution, changed substantially for the otherwise identical catalyst particles. At a working electrode potential of $-0.50 \mathrm{~V}$, $\mathrm{CO}$ and $\mathrm{H}_{2}$ were mostly exclusively formed products with both cell designs. This potential was too low to invoke a significant formation of $\mathrm{C}_{2+}$ products on the $\mathrm{Cu}$ shell (Figure 3, Figure S6 and Table S2).

When measured in the $\mathrm{H}$-cell, $\mathrm{H}_{2}$ is by far the major product at all applied potentials with a faradaic efficiency ranging

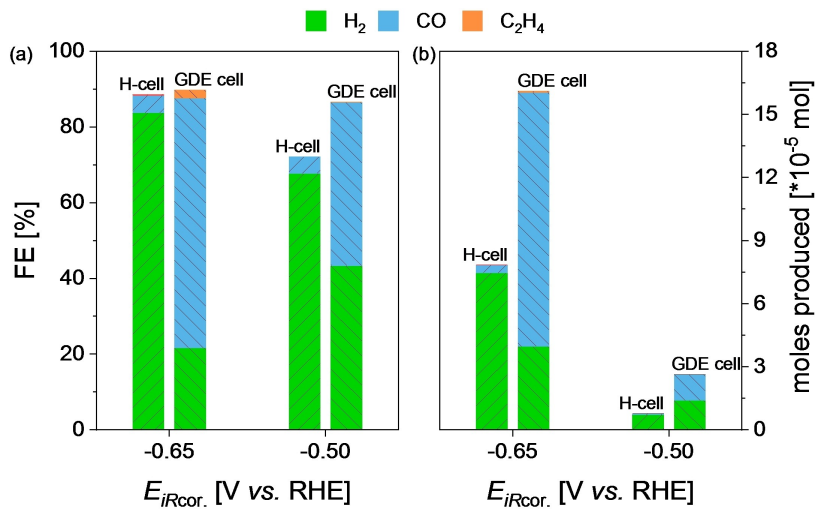

Figure 3. (a) Average faradaic efficiency and (b) mols of product formed for $\mathrm{H}_{2}, \mathrm{CO}$ and $\mathrm{C}_{2} \mathrm{H}_{4}$ at -0.50 and $-0.65 \mathrm{~V}$ vs. $\mathrm{RHE}_{i R c o r}$ after 30 min with the $\mathrm{H}$ cell and GDE cell. Catalyst loading per electrode $\sim 1.6 \mathrm{mg}, \mathrm{n}=2$.

around $80 \%$ and it increases at larger bias potentials. The dominant HER leads to only a small partial current for the $\mathrm{CO}_{2} \mathrm{RR}$ products. In contrast, the $\mathrm{FE}$ for $\mathrm{H}_{2}$ is much smaller with the GDE cell ranging around $27 \%$ and it decreased at higher overpotentials. Moreover, when comparing the $\mathrm{H}$-cell and GDE cell at the same potentials, the $\mathrm{FE}$ for $\mathrm{H}_{2}$ decreased 4 times at $-0.65 \mathrm{~V}$ from $\sim 80 \%$ to $\sim 20 \%$ and 5 times at $-0.80 \mathrm{~V}$ from $\sim 90 \%$ to $\sim 16 \%$. With the suppression of the HER, a larger portion of the current was used for the $\mathrm{CO}_{2} \mathrm{RR}$, consequently, using the GDE cell yielded superior FEs for all detected $\mathrm{CO}_{2}$ reduction products at all measured potentials (Figure 3a and Figure S6). In general, with the faster $\mathrm{CO}_{2}$ mass transport, the GDE presents a more favourable environment for the $\mathrm{CO}_{2} \mathrm{RR}$ over the undesired HER. Whereas all $\mathrm{CO}_{2} \mathrm{RR}$ products add up to a $\mathrm{FE}$ of around $8 \%$ in the case of the $\mathrm{H}$-cell, this value increases to approximately $70 \%$ in the case of the GDE cell at $-0.65 \mathrm{~V}$. The FE of $\mathrm{CO}$ increases around 13 times, whereas the increase in the $\mathrm{C}_{2+}$ products is around 7 times at $-0.65 \mathrm{~V}$. As a consequence of higher faradaic efficiencies, the use of the GDE cell increased significantly the total formed moles of $\mathrm{CO}_{2} \mathrm{RR}$ products (Figure $3 \mathrm{~b}$ ). At $-0.65 \mathrm{~V}$, the amount of $\mathrm{H}_{2}$ produced was two times smaller for the GDE than for the $\mathrm{H}$-cell, whereas the moles of $\mathrm{CO}$ and $\mathrm{C}_{2} \mathrm{H}_{4}$ increased 32 and 17 times, respectively. Furthermore, the partial current for ethylene increased by a factor of 16 at $-0.65 \mathrm{~V}$ in the case of the GDE cell (Table S3). These results suggest that measurements in $\mathrm{CO}_{2}$ saturated electrolytes with a conventional $\mathrm{H}$-cell do not allow for a comprehensive assessment of the intrinsic properties of a catalyst material due to the rapid depletion of $\mathrm{CO}_{2}$ favouring the HER.

The results show, that the proposed cascade mechanism inside the nanoconfined environment within the porous $\mathrm{Cu}$ shell is limited by the $\mathrm{CO}$ formation rate at the $\mathrm{Ag}$ core. It is revealed, that with the $\mathrm{H}$-cell that the small $\mathrm{CO}$ production stems neither from a low intrinsic activity of the $\mathrm{Ag}$ cores nor a $\mathrm{CO}_{2}$ diffusion barrier through the porous $\mathrm{Cu}$ shell, but rather from mass transport limitations inherent to the $\mathrm{H}$-cell configuration and the low solubility of $\mathrm{CO}_{2}$. Once the particles are placed on a GDE the limited $\mathrm{CO}_{2}$ mass transport to the particles 
is mitigated, and the activity of $\mathrm{Ag}$ core/porous $\mathrm{Cu}$ shell nanoparticles as a $\mathrm{CO}_{2}$ reduction catalyst can be accurately addressed and assessed.

The beneficial effects of the GDE become even more apparent at more cathodic potentials, where the previously described trends between the two cell geometries are confirmed. At $-0.80 \mathrm{~V}$ the FE for $\mathrm{H}_{2}$ decreased around 5 times using the GDE cell, whereas the FE for CO increased by 12 times and by 10 times for $\mathrm{C}_{2+}$ products in comparison to the $\mathrm{H}$-cell (Figure S6 and Table S2). These results highlight the selectivity for cascade products (Figure 4). Furthermore, the formation of cascade products increased by about 10 times at $-0.80 \mathrm{~V}$ compared to $-0.65 \mathrm{~V}$ with a FE of $\sim 17 \%$ for ethylene and $\sim 11 \%$ for ethanol in the case of the GDE cell. The FE and the sum of $\mathrm{C}_{2+}$ products partial current increased from $2.3 \%$ and $-0.5 \mathrm{~mA}$ in an H-cell, to $29 \%$ and $-51 \mathrm{~mA}$ with the GDE cell at $-0.8 \mathrm{~V}$. The amount of $\mathrm{C}_{2} \mathrm{H}_{4}$ increased by a factor of 62 when using the GDE cell from $7.8 \times 10^{-7}$ to $4.9 \times 10^{-5}$ mols (Figure $4 b$ ).

We reported previously that the structure of the bimetallic core/shell particles changes at this potential (for further details, see SI and Figures S7). ${ }^{[16]}$ Based on the proposed cascade mechanism, the formation of multi-carbon products is promoted when the original particle structure is present allowing the nanoconfinement of $\mathrm{CO}$. Therefore, the integrity of the $\mathrm{Ag}$ core/porous $\mathrm{Cu}$ shell particles needs to be confirmed which is possible by assessing changes in the product distribution over electrolysis time. If the ratio between the $\mathrm{FE}$ of $\mathrm{C}_{2+}$ and $\mathrm{CO}$ $\left(\mathrm{FE}_{\mathrm{C} 2+/ \mathrm{CO}}\right)$ exhibits a constant value, the particles are considered stable during the measurement. ${ }^{[16]}$ However, if this value decreases over time, the porous $\mathrm{Cu}$ shell is disintegrating and the nanoconfinement capability necessary for the $C_{2+}$ product formation is lost. Figures S9a and b show that the FE for CO and $\mathrm{C}_{2+}$ remained similar throughout the whole experiment at -0.50 and $-0.65 \mathrm{~V}$ for both $\mathrm{H}$-cell and GDE cell experiments. More importantly, the $\mathrm{FE}_{\mathrm{C} 2+/ \mathrm{CO}}$ ratio was relatively constant with a slight decrease at $-0.65 \mathrm{~V}$, revealing the integrity of the $\mathrm{Ag}$ core/porous $\mathrm{Cu}$ shell particles during the measurement. In

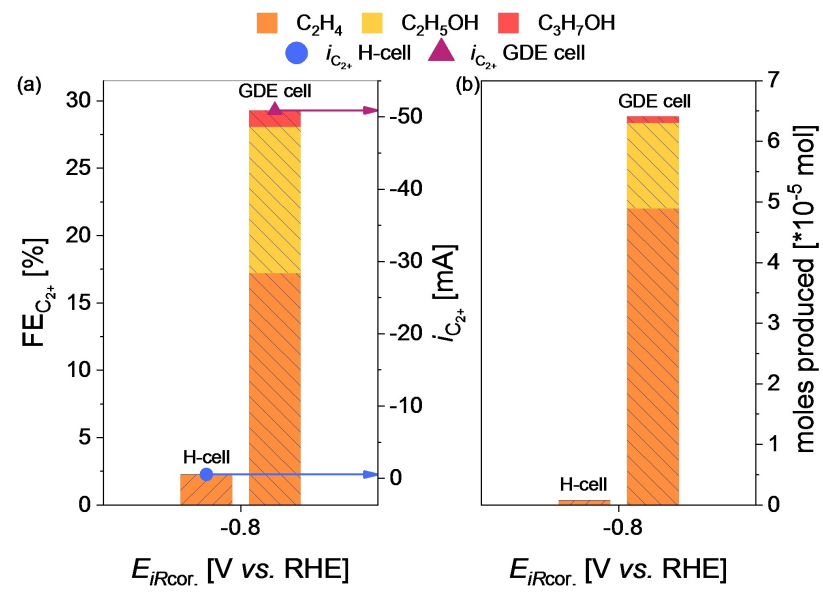

Figure 4. (a) Average FE (left $\mathrm{Y}$-axis) of cascade products $\left(\mathrm{C}_{2+}=\mathrm{C}_{2} \mathrm{H}_{4}\right.$ $+\mathrm{C}_{2} \mathrm{H}_{5} \mathrm{OH}+\mathrm{C}_{3} \mathrm{H}_{7} \mathrm{OH}$ ) and the sum of $\mathrm{C}_{2}$, products partial current (right $\mathrm{Y}$ axis) and (b) number of moles produced at $-0.80 \mathrm{~V} \mathrm{vs}$. $\mathrm{RHE}_{\text {iRcor. }}$ after $30 \mathrm{~min}$ with the H-cell and GDE cell. Catalyst loading per electrode $\sim 1.6 \mathrm{mg}, \mathrm{n}=2$. contrast, at $-0.80 \mathrm{~V}$ (Figure S9c) a significant increase of the FE for $\mathrm{CO}$ in combination with a decrease in the $\mathrm{FE}$ for $\mathrm{C}_{2+}$ is observed with a decrease of the $\mathrm{FE}_{\mathrm{C} 2+/ \mathrm{CO}}$ ratio by more than 5 times during the measurement, which indicates the loss of the porous $\mathrm{Cu}$ shell. These observations are valid for both $\mathrm{H}$-cell and GDE cell, allowing the conclusion that the structural changes of the particles take place in a similar manner regardless of the used electrochemical cell configuration. The particles are stable at -0.50 and $-0.65 \mathrm{~V}$ but lose their structure at $-0.80 \mathrm{~V}$.

However, the measurements at $-0.80 \mathrm{~V}$ in a GDE cell still allow us to assess the performance of the bimetallic catalyst under increased $\mathrm{CO}_{2}$ mass transport conditions enabling the assessment of the whole activity potential of the catalytic material for the $\mathrm{CO}_{2} \mathrm{RR}$. Another indication that the use of a GDE cell at $-0.80 \mathrm{~V}$ is beneficial for the investigation of $\mathrm{CO}_{2} \mathrm{RR}$ catalysts is that at this potential a significant increase in the amount of $C_{3}$ products was shown, with a FE for $n$-propanol reaching up to $1 \%$. Furthermore, one additional $C_{3}$ product, namely allyl alcohol, was detected in the GDE cell. Allyl alcohol was not formed in the $\mathrm{H}$-cell measurements nor our earlier studies ${ }^{[15,16]}$ with such particles (Figure S8).

During $\mathrm{CO}_{2} \mathrm{RR}$ in alkaline electrolytes $\mathrm{H}_{2} \mathrm{O}$ is continuously consumed of and $\mathrm{OH}^{-}$is generated, leading to an accumulation of $\mathrm{OH}^{-}$ions in close proximity to the reaction zone dependent on the reaction rate. Such a change in the local $\mathrm{pH}$ value may affect the product distribution of the electrocatalytic process. ${ }^{[23,24]}$ To investigate these changes a positioned $\mathrm{Pt}$ microelectrode was used as a probe to determine the variation of the local activity ratios of $\mathrm{OH}^{-}$and $\mathrm{H}_{2} \mathrm{O}$ during $\mathrm{CO}_{2} \mathrm{RR}$ with the $\mathrm{H}$-cell and GDE cell configurations at different applied potentials (Figure S10). In these measurements, a Pt microelectrode was firstly positioned in close proximity to the electrode with shear-force based scanning electrochemical microscopy (SECM) (Figure S11). ${ }^{[25]}$ The sensitivity for the local $\mathrm{OH}^{-} / \mathrm{H}_{2} \mathrm{O}$ activity ratios can be extracted from the PtO reduction peak potential $\left(E_{\text {pto-red. peak }}\right.$ ) vs. $\mathrm{Ag}|\mathrm{AgCl}| 3 \mathrm{M} \mathrm{KCl}$ reference electrode (data given in $\mathrm{mV}$ ). In more alkaline electrolytes, the reduction of the $\mathrm{PtO}$ takes place at more cathodic potentials (see $\mathrm{SI}$ ). The experiments were performed using a series of potential pulses. First, a potential equivalent to OCP was applied at the particle-modified electrode $(-250 \mathrm{mV}$ vs. $\mathrm{Ag}$ $\mathrm{AgCl} \mid 3 \mathrm{M} \mathrm{KCl}$ ) followed by a cathodic potential, and to finish OCP was applied again. The particle modified electrode was switched between "ON" and "OFF", while measuring the local $\mathrm{OH}^{-} / \mathrm{H}_{2} \mathrm{O}$ activity ratio. Figure 5 shows the variation of the $E_{\mathrm{ptO}}$ red. peak measured at the $\mathrm{Pt}$ microelectrode when different potentials were applied at the Ag core/porous Cu shell modified electrode for both cell designs. A significant cathodic shift of the $E_{\text {pto-red. peak }}$ was observed after applying the potential in both configurations, followed by an anodic shift when OCP was applied. The results indicate the local increase in the $\mathrm{pH}$ value when $\mathrm{CO}_{2} \mathrm{RR}$ and the potentially competing HER are taking place. Furthermore, at higher applied potential, the $E_{\text {PtO-red. peak }}$ was as expected more negative. The $E_{\text {pto-red. peak }}$ shifts were more pronounced in the GDE cell (Figure $5 \mathrm{c}$ ) in comparison to the $\mathrm{H}$ cell (Figure 5a). Hence, these experimental data show that a 
(a)
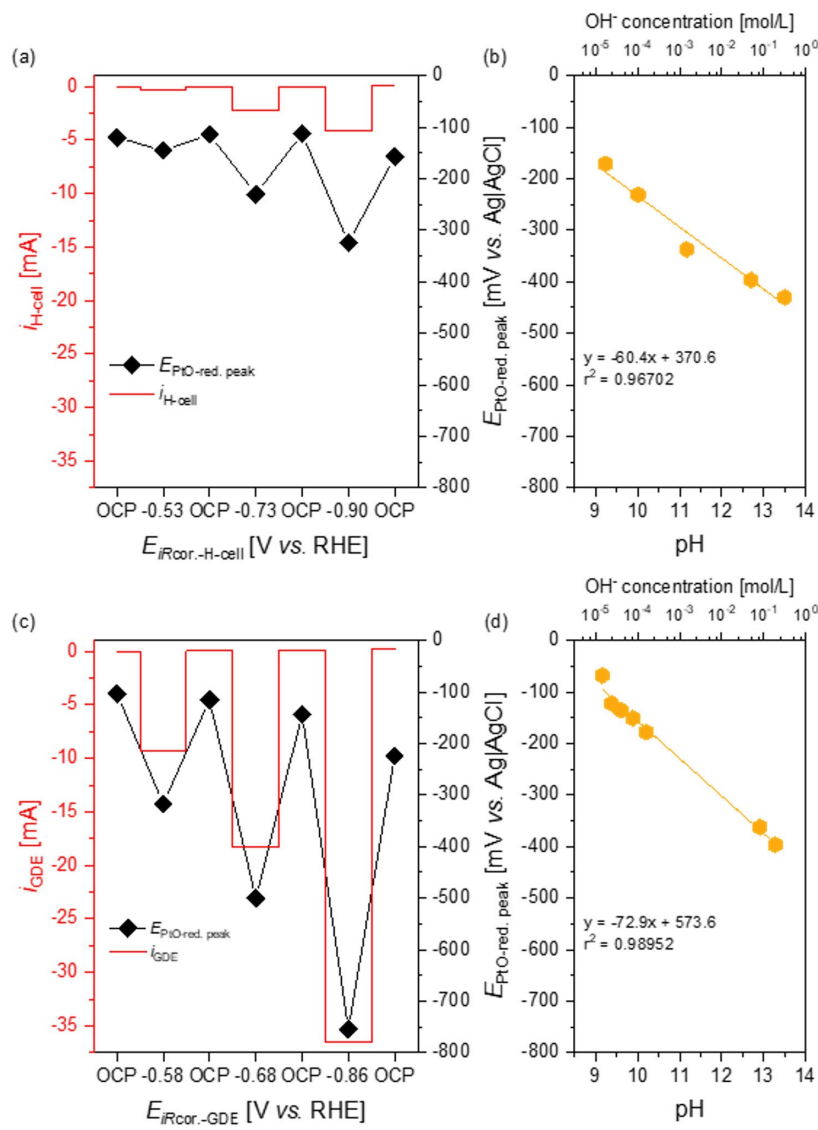

(d)

$\mathrm{OH}^{-}$concentration [mol/L] $10^{5} 10^{4} 10^{3} 10^{2} 10^{-1} 10^{\circ}$

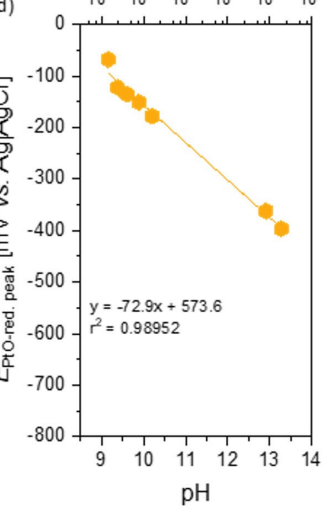

Figure 5. (a) Average current at the $\mathrm{H}$-cell working electrode at different applied potentials (left $\mathrm{Y}$-axis, line plot) and PtO reduction potential peak (right $\mathrm{Y}$-axis, symbol and line plot) in $\mathrm{CO}_{2}$-saturated $1 \mathrm{M} \mathrm{KHCO}_{3}$. (b) Variation of the PtO reduction peak potential in solutions of different $\mathrm{pH}$ values. (c) Average current at the GDE cell working electrode at different applied potentials (left $\mathrm{Y}$-axis, line plot) and PtO reduction potential peak (right $\mathrm{Y}$ axis, symbol and line plot) in Ar-saturated $1 \mathrm{M} \mathrm{KHCO}_{3}(\mathrm{~d})$ variation of the PtO reduction potential peak in solutions of different $\mathrm{pH}$ values. Both working electrodes were prepared with $1 \mathrm{mg} / \mathrm{cm}^{2}$ of Ag core/porous Cu shell. $E_{\mathrm{Pto}}$
red. peak values extracted from the results in Figures S12 and S13.

more drastic local alkalinisation is obtained with a GDE than the $\mathrm{H}$-cell. ${ }^{[18]}$ The obtained values of $E_{\text {pto-red. peak }}$ at different applied potentials can be compared with the measured values from the $\mathrm{Pt}$ probe calibration in solutions of different $\mathrm{pH}$ values (Figures $5 \mathrm{~b}$ and $\mathrm{d}$ and Figure S13). Under operation at -0.68 and $-0.86 \mathrm{~V}$ the GDE cell reached a local activity ratio of $\mathrm{OH}^{-} /$ $\mathrm{H}_{2} \mathrm{O}$ higher than in $1 \mathrm{M} \mathrm{KOH}$. These changes in the $\mathrm{pH}$ value support the effect on the product distributions. The results from the GDE cell showed a continuous decrease in the FE for $\mathrm{H}_{2}$ at higher applied currents (Figure S6) and an increase in the $\mathrm{CO}_{2} \mathrm{RR}$. This can be explained by a combination of a shorter $\mathrm{CO}_{2}$ diffusion pathlength provided by the gas diffusion layer and the high local $\mathrm{OH}^{-}$activities obtained with this cell configuration.

\section{Conclusion}

In summary, the activity and selectivity of the Ag core/porous $\mathrm{Cu}$ shell nanoparticles are limited in an $\mathrm{H}$-cell configuration, which precluded the comprehensive assessment of the full catalytic potential of this and presumably other nanostructured catalysts. In a GDE cell configuration, superior catalytic activity and selectivity for the $\mathrm{CO}_{2} \mathrm{RR}$ were observed, resulting in larger currents and higher $\mathrm{FE}$ for $\mathrm{CO}_{2} \mathrm{RR}$ products. The results elucidated that the particles were limited by the mass transport of reactants to the catalyst, and not within the porous $\mathrm{Cu}$ shell. To compare the results obtained with different reactors, it was vital to perform the measurements with automatic iR compensation to assure that the actual potential at the working electrode was independent of the measured current. Hence, the product distribution could be compared at the same applied potential using different cell designs. When the $\mathrm{CO}_{2}$ mass transport limitations were removed using the GDE cell, a significant decrease in $\mathrm{H}_{2}$ formation followed by an increase in $\mathrm{CO}_{2} \mathrm{RR}$ products formation was observed. The results reveal that the $\mathrm{CO}_{2} \mathrm{RR}$ performance of the Ag core/porous $\mathrm{Cu}$ shell particles improved at increased $\mathrm{CO}_{2}$ mass transport conditions and higher currents. A significant increase in the $F E$ for $C_{2}$ and $C_{3}$ products were observed when the catalyst particles were measured in the GDE cell. The measurement results highlight the distinct difference in the electrochemical environment in terms of the local $\mathrm{pH}$ value between $\mathrm{H}$-cell and GDE cell, with alkalinisation being more pronounced in the case of the GDE cell. Hence, the GDE cell configuration grants improved conditions to evaluate the performance of the electrocatalyst material for the $\mathrm{CO}_{2} \mathrm{RR}$ concomitantly making HER less favourable.

\section{Acknowledgements}

This project has received funding from the European Research Council (ERC) under the European Union's Horizon 2020 research and innovation programme (grant agreement CasCat [833408]) as well as from the Deutsche Forschungsgemeinschaft (DFG, German Research Foundation) in the framework of the research unit FOR $2397 e 2$ (276655237). C.A. acknowledges funding by the BMBF in the framework of the NanomatFutur project "MatGasDif" (03XP0263). The Australian team acknowledges funding from the Australian Research Council (DP190102659, RDT, WS and DP210102698, JJG). Open Access funding enabled and organized by Projekt DEAL.

\section{Conflict of Interest}

The authors declare no conflict of interest.

Keywords: AgCu nanoparticles $\cdot \mathrm{CO}_{2}$ reduction $\cdot \mathrm{C}_{2+}$ products $\cdot$ gas diffusion electrode $\cdot$ local $\mathrm{pH}$
[1] R. K. Pachauri, L. Meyer, Climate change 2014. Synthesis report, Intergovernmental Panel on Climate Change, Geneva, Switzerland, 201

[2] Z. Sun, T. Ma, H. Tao, Q. Fan, B. Han, Chem 2017, 3, 560. 
[3] a) B. Khezri, A. C. Fisher, M. Pumera, J. Mater. Chem. A 2017, 5, 8230; b) L. Fan, C. Xia, F. Yang, J. Wang, H. Wang, Y. Lu, Sci. Adv. 2020, 6, eaay3111.

[4] G. Wang, J. Chen, Y. Ding, P. Cai, L. Yi, Y. Li, C. Tu, Y. Hou, Z. Wen, L. Dai, Chem. Soc. Rev. 2021, 50, 4993.

[5] K. Jiang, Y. Huang, G. Zeng, F. M. Toma, W. A. Goddard, A. T. Bell, ACS Energy Lett. 2020, 5, 1206.

[6] Y. Hori in Handbook of Fuel Cells (Eds.: W. Vielstich, A. Lamm, H. A. Gasteiger, H. Yokokawa), John Wiley \& Sons, Ltd, Chichester, UK, 2010.

[7] a) C. W. Li, J. Ciston, M. W. Kanan, Nature 2014, 508, 504; b) W. Zhu, B. M. Tackett, J. G. Chen, F. Jiao in Topics in Current Chemistry Collections (Ed.: M. Shao), Springer International Publishing, Cham, 2020, pp. 105-125; c) A. Vasileff, C. Xu, Y. Jiao, Y. Zheng, S.-Z. Qiao, Chem 2018, 4, 1809; d) C. G. Morales-Guio, E. R. Cave, S. A. Nitopi, J. T. Feaster, L. Wang, K. P. Kuhl, A. Jackson, N. C. Johnson, D. N. Abram, T. Hatsukade, C. Hahn, T. F. Jaramillo, Nat. Catal. 2018, 1, 764.

[8] Y. Hori, K. Kikuchi, S. Suzuki, Chem. Lett. 1985, 14, 1695.

[9] C. W. Li, M. W. Kanan, J. Am. Chem. Soc. 2012, 134, 7231.

[10] D. Ren, B. S.-H. Ang, B. S. Yeo, ACS Catal. 2016, 6, 8239.

[11] J. Gao, H. Zhang, X. Guo, J. Luo, S. M. Zakeeruddin, D. Ren, M. Grätzel, J. Am. Chem. Soc. 2019, 141, 18704.

[12] S. Lee, G. Park, J. Lee, ACS Catal. 2017, 7, 8594.

[13] a) T. T. H. Hoang, S. Verma, S. Ma, T. T. Fister, J. Timoshenko, A. I. Frenkel, P. J. A. Kenis, A. A. Gewirth, J. Am. Chem. Soc. 2018, 140, 5791; b) A. Herzog, A. Bergmann, H. S. Jeon, J. Timoshenko, S. Kühl, C. Rettenmaier, M. Lopez Luna, F. T. Haase, B. Roldan Cuenya, Angew. Chem. Int. Ed. 2021, 60, 7426; c) D. Higgins, A. T. Landers, Y. Ji, S. Nitopi, C. G. MoralesGuio, L. Wang, K. Chan, C. Hahn, T. F. Jaramillo, ACS Energy Lett. 2018, 3, 2947; d) D. Ren, J. Gao, S. M. Zakeeruddin, M. Grätzel, Chimia 2019, 73, 928.

[14] J. Huang, M. Mensi, E. Oveisi, V. Mantella, R. Buonsanti, J. Am. Chem. Soc. 2019, 141, 2490.
[15] P. B. O'Mara, P. Wilde, T. M. Benedetti, C. Andronescu, S. Cheong, J. J. Gooding, R. D. Tilley, W. Schuhmann, J. Am. Chem. Soc. 2019, 141, 14093.

[16] P. Wilde, P. B. O'Mara, J. R. C. Junqueira, T. Tarnev, T. M. Benedetti, C. Andronescu, Y.-T. Chen, R. D. Tilley, W. Schuhmann, J. J. Gooding, Chem. Sci. 2021, 12, 4028.

[17] a) M. Duarte, B. de Mot, J. Hereijgers, T. Breugelmans, ChemElectroChem 2019, 6, 5596; b) L.-C. Weng, A. T. Bell, A. Z. Weber, Phys. Chem. Chem. Phys. 2018, 20, 16973; c) N. T. Nesbitt, T. Burdyny, H. Simonson, D. Salvatore, D. Bohra, R. Kas, W. A. Smith, ACS Catal. 2020, 10, 14093.

[18] T. Burdyny, W. A. Smith, Energy Environ. Sci. 2019, 12, 1442.

[19] C. Chen, Y. Li, S. Yu, S. Louisia, J. Jin, M. Li, M. B. Ross, P. Yang, Joule 2020, 4, 1688.

[20] Z. Li, R. M. Yadav, L. Sun, T. Zhang, J. Zhang, P. M. Ajayan, J. Wu, Appl. Catal. A 2020, 606, 117829.

[21] X. She, T. Zhang, Z. Li, H. Li, H. Xu, J. Wu, Cell. Rep. Phys. Sci. 2020, 1, 100051.

[22] J. Wu, X. Wang, Q. Wang, Z. Lou, S. Li, Y. Zhu, L. Qin, H. Wei, Chem. Soc. Rev. 2019, 48, 1004.

[23] K. J. P. Schouten, E. Pérez Gallent, M. T. Koper, J. Electroanal. Chem. 2014, 716, 53.

[24] R. Kortlever, J. Shen, K. J. P. Schouten, F. Calle-Vallejo, M. T. M. Koper, J. Phys. Chem. Lett. 2015, 6, 4073.

[25] a) A. Botz, J. Clausmeyer, D. Öhl, T. Tarnev, D. Franzen, T. Turek, W. Schuhmann, Angew. Chem. Int. Ed. 2018, 57, 12285; b) S. Dieckhöfer, D. Öhl, J. R. C. Junqueira, T. Quast, T. Turek, W. Schuhmann, Chem. Eur. J. 2021, 27, 5906; c) N. Sikdar, J. R. C. Junqueira, S. Dieckhöfer, T. Quast, M. Braun, Y. Song, H. B. Aiyappa, S. Seisel, J. Weidner, D. Öhl, C. Andronescu, W. Schuhmann, Angew. Chem. Int. Ed. 2021, 60, 23427.

Manuscript received: July 3, 2021

Revised manuscript received: November 18, 2021

Accepted manuscript online: November 24, 2021 